\title{
Isolation and Propagation of Laboratory Strains and a Novel Flea-Derived Field Strain of Wolbachia in Tick Cell Lines
}

\author{
Jing Jing Khoo ${ }^{1}$, Timothy J. Kurtti ${ }^{2}$, Nurul Aini Husin ${ }^{1}$, Alexandra Beliavskaia ${ }^{3}$, \\ Fang Shiang Lim ${ }^{1}$, Mulya Mustika Sari Zulkifli ${ }^{1}$, Alaa M. Al-Khafaji ${ }^{3,4}$, Catherine Hartley ${ }^{3}$, \\ Alistair C. Darby ${ }^{3}$, Grant L. Hughes ${ }^{5}{ }^{\oplus}$, Sazaly AbuBakar ${ }^{1}$, Benjamin L. Makepeace ${ }^{3}$ and \\ Lesley Bell-Sakyi ${ }^{3, *(D)}$ \\ 1 Tropical Infectious Diseases Research and Education Centre, Level 2, High Impact Research Building, \\ University of Malaya, Kuala Lumpur 50603, Malaysia; jing.khoo@um.edu.my (J.J.K.); \\ nurulainihusin@yahoo.com (N.A.H.); limfs92@gmail.com (F.S.L.); mulyamustika@um.edu.my (M.M.S.Z.); \\ sazaly@um.edu.my (S.A.) \\ 2 Department of Entomology, University of Minnesota, 219 Hodson Hall, 1980 Folwell Avenue, Saint Paul, \\ MN 55108, USA; kurtt001@umn.edu \\ 3 Department of Infection Biology and Microbiome, Institute of Infection, Veterinary and Ecological Sciences, \\ University of Liverpool, 146 Brownlow Hill, Liverpool L3 5RF, UK; alexbel@liverpool.ac.uk (A.B.); \\ csguy@liverpool.ac.uk (C.H.); acdarby@liverpool.ac.uk (A.C.D.); blm1@liverpool.ac.uk (B.L.M.) \\ 4 College of Veterinary Medicine, University of Al-Qadisiyah, Qadisiyah 54004, Iraq; supervisore2@yahoo.com \\ 5 Departments of Vector Biology and Tropical Disease Biology, Centre for Neglected Tropical Disease, \\ Liverpool School of Tropical Medicine, Pembroke Place, Liverpool L3 5QA, UK; Grant.Hughes@lstmed.ac.uk \\ * Correspondence: L.Bell-Sakyi@liverpool.ac.uk
}

Received: 10 June 2020; Accepted: 30 June 2020; Published: 1 July 2020

check for updates

\begin{abstract}
Wolbachia are intracellular endosymbionts of several invertebrate taxa, including insects and nematodes. Although Wolbachia DNA has been detected in ticks, its presence is generally associated with parasitism by insects. To determine whether or not Wolbachia can infect and grow in tick cells, cell lines from three tick species, Ixodes scapularis, Ixodes ricinus and Rhipicephalus microplus, were inoculated with Wolbachia strains $w$ Stri and wAlbB isolated from mosquito cell lines. Homogenates prepared from fleas collected from cats in Malaysia were inoculated into an I. scapularis cell line. Bacterial growth and identity were monitored by microscopy and PCR amplification and sequencing of fragments of Wolbachia genes. The wStri strain infected Ixodes spp. cells and was maintained through 29 passages. The wAlbB strain successfully infected Ixodes spp. and R. microplus cells and was maintained through 2-5 passages. A novel strain of Wolbachia belonging to the supergroup $\mathrm{F}$, designated $w \mathrm{CfeF}$, was isolated in I. scapularis cells from a pool of Ctenocephalides sp. cat fleas and maintained in vitro through two passages over nine months. This is the first confirmed isolation of a Wolbachia strain from a flea and the first isolation of any Wolbachia strain outside the "pandemic" A and B supergroups. The study demonstrates that tick cells can host multiple Wolbachia strains, and can be added to panels of insect cell lines to improve success rates in isolation of field strains of Wolbachia.
\end{abstract}

Keywords: Wolbachia; tick cell line; Ctenocephalides; flea; Malaysia; in vitro culture; phylogeny

\section{Introduction}

Wolbachia is a genus of obligate intracellular endosymbiotic gram-negative bacteria of the family Anaplasmataceae in the order Rickettsiales. Wolbachia infect two phyla in the Ecdysozoa: 
the Arthropoda and the Nematoda, with a much broader range of host species in the former than in the latter. Although only one species, Wolbachia pipientis, has been formally described [1], the genus has been separated by multi-locus sequence typing (MLST) into 18 clades or "supergroups" [2-4]. Core genome alignments for supergroups suggest that they can be considered at least equivalent to species rank, with some containing sufficient diversity for more than one species [5]. Wolbachia is best known for its ability to induce five distinct reproductive manipulations in arthropod hosts (cytoplasmic incompatibility (CI), induction of parthenogenesis, male killing, feminisation and meiotic drive), all of which favour its spread by reducing resource competition from males (a dead-end host) or imposing a fitness cost on uninfected females [6-9]. However, these parasitic phenotypes appear to be largely confined to the "pandemic" supergroups A and B that infect $~ 50 \%$ of terrestrial arthropod species $[10,11]$. In other cases, Wolbachia form obligate and putatively beneficial relationships with their hosts, including strains from supergroups $C$ and $D$ in nematodes and $E$ in springtails $[12,13]$.

Wolbachia is found in most of the major groups of haematophagous arthropods, including biting Diptera and Hemiptera, fleas, lice and parasitic mites [14-26]. The CI phenotype, in which the progeny of crosses between infected males and uninfected females (or females carrying an incompatible Wolbachia strain) die early in development, is common in blood-feeding Diptera $[21,25,27]$. In contrast, a supergroup F Wolbachia strain in bedbugs is a nutritional mutualist, providing B vitamins for its host that are deficient in the blood meal $[18,20]$. Wolbachia has long been of applied interest for disease control, as release of Wolbachia-infected male pest insects can suppress natural populations where the females are uninfected or harbour an incompatible strain [28]. In filarial nematodes that cause neglected tropical diseases such as onchocerciasis and lymphatic filariasis, elimination of Wolbachia using antibiotics can safely clear adult worm infections, unlike conventional anthelmintics [29]. Finally, Wolbachia infections can suppress the dissemination and transmission of pathogens in insects, especially when transinfected into a novel host [30]. This phenomenon is the basis for several control programmes releasing Wolbachia-infected Aedes aegypti to reduce the transmission of dengue and other arboviruses [31].

The order Ixodida is the only large group of haematophagous arthropods in which the status of Wolbachia infections still remains ambiguous. While many studies have reported the presence of Wolbachia in ticks using molecular methods [32-45], it is unclear whether ticks are themselves infected with Wolbachia, or if the bacteria are present within cells of species of the parasitic wasp genus Ixodiphagus [46] or other parasites of ticks such as nematodes [39] or mites. Recent studies have yielded strong indications that the latter scenario may be the correct one, as Wolbachia-positive Ixodes ricinus ticks are almost always positive for Ixodiphagus DNA [47,48].

However, the question remains whether or not tick cells are capable of supporting infection and growth of Wolbachia. To answer this, we first tested the ability of cell lines with known broad susceptibility to infection with intracellular bacteria, derived from I. ricinus, Ixodes scapularis and Rhipicephalus microplus, to support the replication of two laboratory strains of Wolbachia derived from different insect hosts. We then applied an I. scapularis cell line in an attempt to isolate Wolbachia or other intracellular bacteria from field-collected fleas in Malaysia.

\section{Materials and Methods}

\subsection{Tick Cell Lines}

The I. scapularis cell lines ISE6 [49] and ISE18 [50] and the I. ricinus cell line IRE11 [51] were maintained at $28{ }^{\circ} \mathrm{C}$ or $32{ }^{\circ} \mathrm{C}$ in L-15C300 medium supplemented with $10 \%$ tryptose phosphate broth (TPB), $10 \%$ foetal bovine serum (FBS) and $0.1 \%$ bovine lipoprotein (MP Biomedicals, Solon, $\mathrm{OH}, \mathrm{USA}$ ) [52]. The I. scapularis cell line IDE8 [50] was maintained in flat-sided culture tubes (Nunc, Thermo Fisher, Loughborough, UK) at $32{ }^{\circ} \mathrm{C}$ in L-15B medium [53] supplemented with $10 \%$ TPB, $10 \% \mathrm{FBS}, 0.1 \%$ bovine lipoprotein, $2 \mathrm{mM} \mathrm{L}$-glutamine and antibiotics (100 units/mL penicillin and $100 \mu \mathrm{g} / \mathrm{mL}$ streptomycin). The R. microplus cell line BME/CTVM23 [54] was maintained in flat-sided 
culture tubes at $28^{\circ} \mathrm{C}$ in L-15 (Leibovitz) medium supplemented with 10\% TPB, 20\% FBS, 2 mM L-glutamine and antibiotics. All cell lines were maintained with weekly medium change and subculture at 1-3 monthly intervals.

\subsection{Wolbachia Strains}

For experiments with Ixodes spp. cell lines, the wStri strain, originally isolated from the small brown planthopper Laodelphax striatellus into the Aedes albopictus cell line NIAS-AeAl-2 [55] and kindly provided by H. Noda, National Institute of Agrobiological Sciences, Tsukuba, Japan [56], was propagated in AeAl-2 cells maintained in L-15C300 supplemented as above. The wAlbB strain, originally isolated from the mosquito Ae. albopictus into the Ae. albopictus cell line Aa23 [57] and kindly provided by S.L. Dobson, University of Kentucky, was propagated in Aa23 cells also maintained in supplemented L-15C300 medium. For experiments with the $R$. microplus cell line BME/CTVM23, the wAlbB strain, originally provided by Scott O'Neill, Yale University School of Medicine, was transferred from Aa23 cells to Ae. albopictus C6/36 cells [58] maintained in a 1:1 mixture of Schneider's modified Drosophila medium (Merck, Sigma Aldrich, Gillingham, UK) and Mitsuhashi and Maramorosch medium (Geneflow Custom Media, Geneflow, Lichfield, UK) supplemented with $10 \%$ FBS and $2 \mathrm{mM}$ L-glutamine. Infected mosquito cell cultures were maintained at $28^{\circ} \mathrm{C}$ with weekly medium change and occasional subculture.

\subsection{Preparation of Cell-Free Wolbachia Suspensions and Inoculation of Tick Cell Lines}

For experiments with wAlbB and wStri in Ixodes spp. cell lines, cell-free Wolbachia were initially used to inoculate tick cell cultures. Wolbachia were released from heavily infected Ae. albopictus cells by forcibly passing infected cell suspensions through a $25 \mathrm{G}$ needle. The resultant suspension was filtered through a $2 \mu \mathrm{m}$ syringe filter and inoculated into tick cell cultures. To enhance infection rates, filtered Wolbachia were transferred to a $2 \mathrm{~mL}$ microfuge tube containing tick cells $\left(1-2 \times 10^{6}\right.$ cells $/ \mathrm{mL}$ in $\left.1.5 \mathrm{~mL}\right)$ centrifuged at $5000 \times g$ for $5 \mathrm{~min}$ and allowed to sit at room temperature for $30 \mathrm{~min}$ prior to seeding into culture flasks [59]. Cultures were incubated at $28{ }^{\circ} \mathrm{C}(w \mathrm{AlbB})$ or $32{ }^{\circ} \mathrm{C}$ (wStri). Once established in tick cell lines, Wolbachia were maintained by inoculating uninfected tick cell cultures with a suspension of infected cells at dilutions of 1:5 for $w$ AlbB and 1:10-1:20 for $w$ Stri.

For experiments with wAlbB in $R$. microplus cells, a $1.2 \mathrm{~mL}$ aliquot of resuspended infected C6/36 cells was diluted with a further $0.5 \mathrm{~mL}$ Schneider's modified Drosophila medium, passed ten times through a bent 26-gauge needle and centrifuged at $1500 \times g$ for $5 \mathrm{~min}$. A $0.3 \mathrm{~mL}$ aliquot of the supernate was added to a $2.2 \mathrm{~mL}$ culture of BME/CTVM23 cells in a flat-sided culture tube, and to an uninfected culture of C6/36 cells in L-15 (Leibovitz) medium supplemented as above but with 10\% FBS, in a flat-sided tube. Cultures were incubated at $28^{\circ} \mathrm{C}$; once established, Wolbachia were subcultured by passaging resuspended infected BME/CTVM23 onto fresh cells at a dilution of 1:10.

\subsection{Preparation of Homogenate from Field-Collected Fleas}

Ctenocephalides sp. fleas were collected from domestic cats from a village of indigenous people, also known as the Orang Asli, in Perak, Malaysia $\left(4^{\circ} 18^{\prime} 53^{\prime \prime} \mathrm{N}, 100^{\circ} 55^{\prime} 49^{\prime \prime} \mathrm{E}\right)$. All field sampling was conducted with the approval of the University of Malaya Institutional Animal Care and Use Committee as well as the Department of Orang Asli Development in Malaysia. Live fleas were immobilised at $-80{ }^{\circ} \mathrm{C}$ for $15 \mathrm{~min}$ and identified to genus level using morphological keys [60], followed by surface decontamination by immersing the fleas into $0.1 \%$ benzalkonium chloride solution for $5 \mathrm{~min}$. The fleas were then rinsed with $70 \%$ ethanol followed by sterile water and allowed to dry on a piece of sterile filter paper. The flea exoskeleton was cut open with a sterile needle to separate the internal organs from the exoskeleton. Organs from five individual fleas were pooled and transferred into flat-sided culture tubes previously seeded with IDE8 cells in complete L-15B medium containing antibiotics. The combined cell and organ cultures were maintained at $28^{\circ} \mathrm{C}$ with weekly medium change ( $3 / 4$ volume). Once bacterial 
infection was established, subculture was performed by transferring $0.2 \mathrm{~mL}$ of supernate from the infected culture to a fresh tube of IDE8 cells.

\subsection{Examination of Wolbachia-infected Cultures by Microscopy}

Live infected tick cell cultures were monitored by weekly inverted microscope examination. At intervals of 1-7 weeks post inoculation (p.i.) for cultures inoculated with $w$ AlbB and $w$ Stri, and at 8 months p.i. for cultures inoculated with flea organs, tick cells were resuspended by pipetting and cytocentrifuge smears were prepared from small aliquots $(\sim 50 \mu \mathrm{L})$ of cell suspension, stained with Giemsa and examined at $\times 500-1000$ magnification. Wolbachia-infected BME/CTVM23 cells were prepared for transmission electron microscopy as described previously [61].

\subsection{Molecular Confirmation of Wolbachia and Host Cell Identity}

At intervals, 200-500 $\mu \mathrm{L}$ samples of whole culture suspension were collected and DNA was extracted using commercial kits (Qiagen, Germantown, MD, USA; Qiagen, Manchester, UK; Macherey-Nagel, Düren, Germany) following the manufacturers' instructions. Standard PCR amplification of fragments of the pan-bacterial $16 \mathrm{~S}$ rRNA sequence and Wolbachia wsp, coxA, fbpA, $f t s Z, h c p A$ and gatB genes was carried out according to published protocols [3,33]. All standard PCR amplifications included a negative control (water) and appropriate positive controls: DNA extracted from wStri-infected NIAS-AeAl-2 cells, wAlbB-infected Aa23 or C6/36 cells for Wolbachia-specific PCRs or Rickettsia raoultii-infected BME/CTVM23 cells [62] for the pan-bacterial 16S rRNA PCR. PCR products were visualised by agarose gel electrophoresis, and positive PCR products were purified using commercial kits (Qiagen, Germantown, MD, USA; New England Biolabs, Hitchin, UK; Macherey-Nagel, Düren, Germany) and sequenced from both ends using a Sanger sequencing service. To confirm the identity of the bacteria in wAlbB-infected BME/CTVM23 cells and the absence of contaminating mosquito cells, qPCR amplification of fragments of the Wolbachia $16 \mathrm{~S}$ rRNA and mosquito 18S rRNA genes was carried out as described previously [63]. Wolbachia counts were normalised against tick cell counts generated by the amplification of fragments of the tick rpl6 gene as described previously [64]. All qPCR assays were run on a CFX Connect Real-Time PCR Detection System (Bio Rad, Watford, UK). A dilution series of synthetic oligonucleotides representing the full-length amplicons were used as standards for quantification by linear regression in CFX Manager software.

\subsection{Sequence and Phylogenetic Analyses}

Pair-end sequences obtained from PCR amplicons were assembled to produce a corrected consensus using 4Peaks (Nucleobytes B.V., Aalsmeer, The Netherlands) and Clustal Omega [65]. The sequences were then compared with published sequences using BLASTN against the non-redundant database at the National Center for Biotechnology Information (NCBI) GenBank and the Wolbachia MLST database on PubMLST [66]. The sequences were quality-trimmed manually and aligned with voucher sequences using Clustal Omega [65]. The phylogenetic relationship of the novel Wolbachia sp. isolated in this study with other existing Wolbachia sp. was inferred using the Bayesian Markov chain Monte Carlo in MrBayes 3.2 [67], with codon partitions, two runs of 3 million generations, four chains per run, sampling every 1000 trees generated and burn-in of $25 \%$ trees for each dataset. The best-fit model of nucleotide substitution was estimated by Akaike information criterion (AIC) as implemented in jModelTest 2.1.7 [68]. The models selected were GTR+G+I for $16 \mathrm{~S}$ rRNA, GTR+G for concatenated genes of the Wolbachia MLST scheme [3], GTR+I for coxA, HKY+G for $f b p A$ and GTR+G for the remaining genes. 


\section{Results}

\subsection{Propagation of Wolbachia Strains wStri and wAlb1 in Ixodes spp. Cell Lines}

Cell-free Wolbachia strain wStri bacteria, harvested from heavily-infected AeAl-2 cells (Figure 1a), were initially used to infect ISE6, ISE18 and IRE11 cells. Once infection was established (Figure 1b), $w$ Stri grew equally well in all three tick cell lines, and was routinely maintained in ISE6 cells by diluting infected cells with uninfected cells 1:10 or 1:20 every 10 to 20 days through 29 passages over a 14-month period. Cell-free Wolbachia harvested from infected ISE6 cells were pleomorphic, including round, rod- and crescent-shaped bacteria (Figure 1c). There was a pathological effect of $w$ Stri on ISE6 cells (Figure 1d) and it was necessary to subculture infected cells onto fresh cell layers. Infected cells were hypertrophied and pyknotic.

Cell-free Wolbachia strain wAlbB bacteria, harvested from heavily-infected Aa23 cells, were initially used to infect ISE6, ISE18 and IRE11 cells. All three cell lines were successfully infected; wAlbB grew more slowly than wStri, without causing any obvious cytopathic effects, and was routinely maintained in ISE6 cells by diluting infected cells with uninfected cells 1:5 every 4 weeks through 5 passages over a 5-month period.
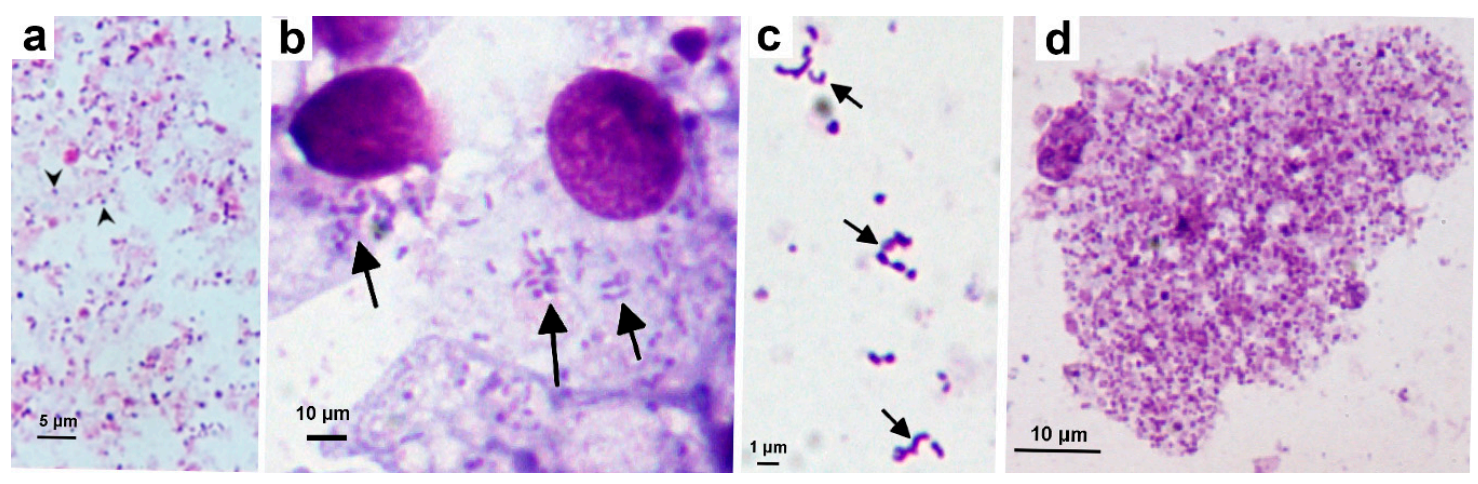

Figure 1. Wolbachia strain wStri propagated in the Ixodes scapularis cell line ISE6. (a) Inoculum comprising cell-free Wolbachia (arrowheads) harvested from AeAl-2 mosquito cells; (b) ISE6 cells infected with $w$ Stri (arrows) at passage 19; (c) Cell-free Wolbachia (arrows) harvested from infected ISE6 cells 2 weeks post infection; (d) Heavily-infected ISE6 cell, 4 weeks after passage of infected cells onto uninfected cell layer. Giemsa-stained cytocentrifuge smears.

\subsection{Propagation of Wolbachia Strain wAlbB in a R. microplus Cell Line}

A single BME/CTVM23 culture was inoculated with cell-free wAlbB bacteria harvested from C6/36 cells and incubated at $28{ }^{\circ} \mathrm{C}$. A single C6/36 culture was inoculated at the same time as a positive control. Weekly inverted microscope examination did not reveal any obvious deleterious effects on the tick or mosquito cells. Intracellular bacteria were detected 2 weeks p.i. in both tick and mosquito cells; as expected, the C6/36 cells were heavily infected by week 4, while in BME/CTVM23 cells the bacteria gradually increased in both infection rate (from $<1 \%$ to $5 \%$ cells infected) and infection level (from $<10$ to $>50$ bacteria per cell) over the subsequent 4 months. Then, during the following 6 weeks, the bacterial growth rate increased rapidly until around $50 \%$ of cells were infected with up to $>100$ bacteria visible per cell. At this point the first subculture onto fresh BME/CTVM23 cells was carried out; four weeks later this passage 1 culture was heavily infected and was passaged onto fresh BME/CTVM23 cells after a further 7 weeks. The passage 2 culture displayed a heavy infection between 8 and 12 weeks later (Figure 2a,b). 


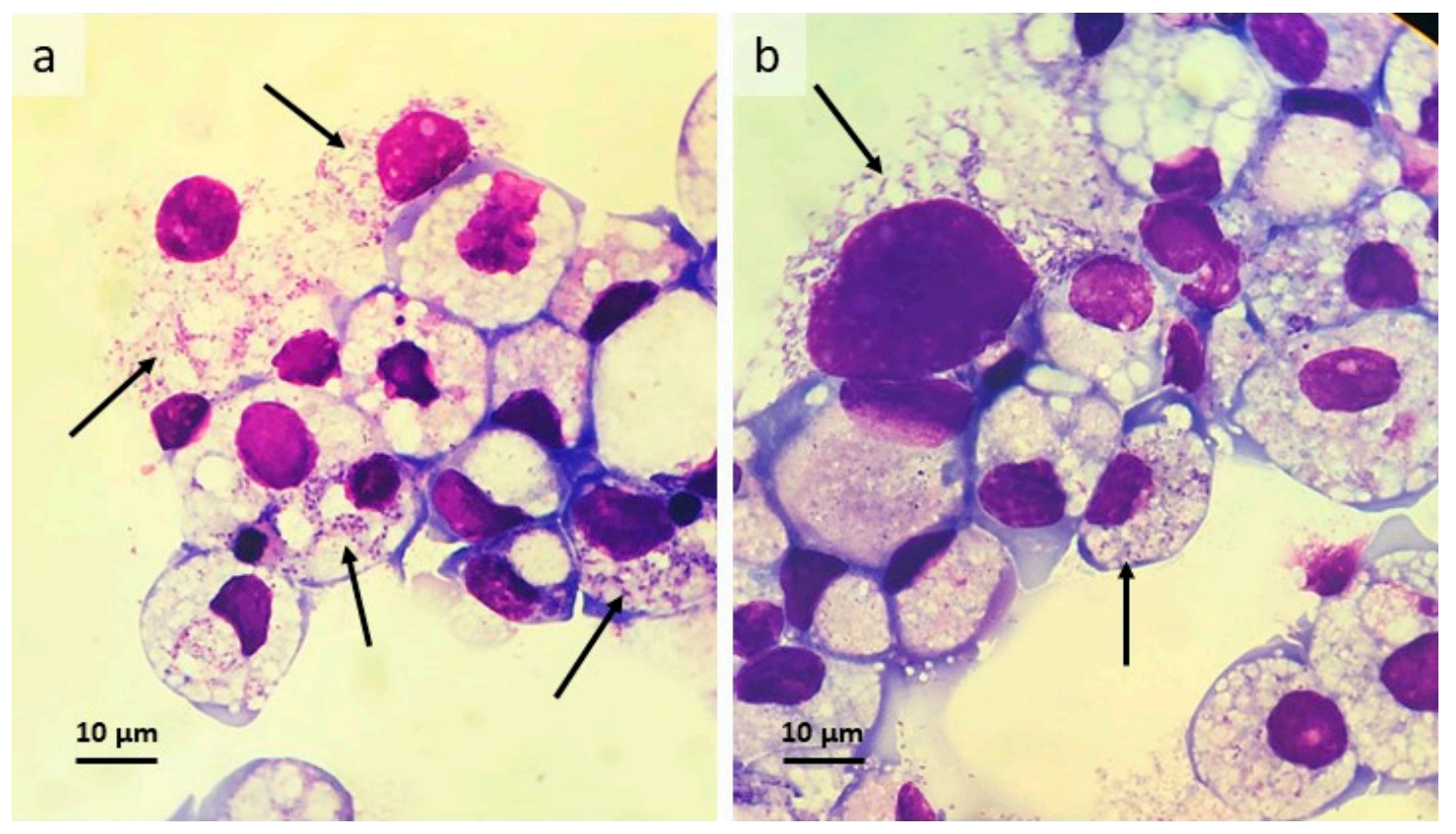

Figure 2. Rhipicephalus microplus cell line BME/CTVM23 infected with Wolbachia strain wAlbB at passage 2, 8 months after initial infection. $(\mathbf{a}, \mathbf{b})$ Giemsa-stained cytocentrifuge smears, arrows indicate heavily-infected cells.

Transmission electron microscope examination of wAlbB-infected BME/CTVM23 cells at passage 1, 10 months after initial infection, revealed putative double membrane-bound bacteria resembling Wolbachia propagated in infected mosquito cell lines [56,69] and observed in the sand flea Tunga penetrans [14], the filarial nematode Brugia malayi [70] and the fruit fly Drosophila melanogaster [71]. Bacteria were seen either within membrane-bound compartments shared with a variety of structures including host-cell components (membranous whorls) and possible vesicles of bacterial origin, as reported previously [70] (Figure 3a-d,f,g), or apparently free in the cytoplasm (Figure 3e,g). These structures were easily distinguished from host cell mitochondria in which cristae were visible (Figure $3 b, f, g$ ).

Amplification by Wolbachia 16S rRNA qPCR confirmed the identity of the bacteria in the cultures and revealed a $w$ AlbB infection level in the BME/CTVM23 cells of over 1000 bacteria per haploid host genome-equivalent. The failure to amplify by $\mathrm{qPCR}$ any product from the same sample using mosquito $18 \mathrm{~S}$ rRNA primers confirmed the absence of contaminating C6/36 cells in the infected tick cell culture. 

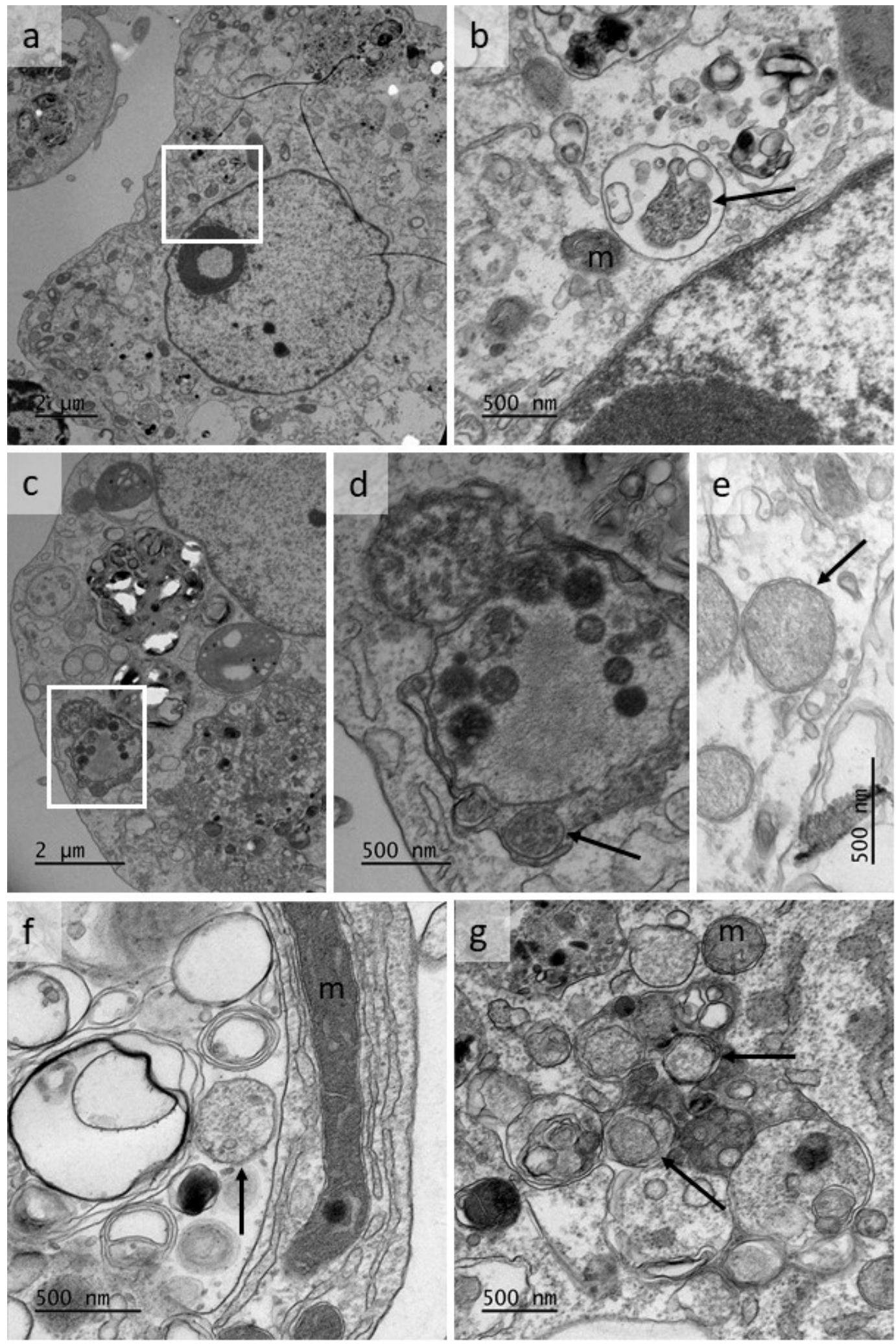

Figure 3. Transmission electron micrographs showing putative bacteria in the cytoplasm of cells of a culture of the Rhipicephalus microplus cell line BME/CTVM23 infected with Wolbachia strain $w A l b B$. The cells were processed from a passage 1 culture, 10 months after initial infection; $\mathrm{m}=$ mitochondrion. $(\mathbf{a}, \mathbf{c})$ low magnification views of infected cells; $(\mathbf{b}, \mathbf{d})$ enlarged areas of cells shown in a, c respectively, showing bacteria-like structures (arrows); $(\mathbf{e}, \mathbf{f}, \mathbf{g})$ bacteria-like structures in BME/CTVM23 cell cytoplasm (arrows). 


\subsection{Isolation and Propagation of a Novel Wolbachia Strain from Malaysian Cat Fleas}

Seven pools of flea organs were inoculated into separate IDE8 cell cultures; of these, a single pool of five individual Ctenocephalides sp. female flea organs yielded a Wolbachia 16S rRNA and wsp PCR-positive culture. A fragment of the Wolbachia wsp gene was amplified from DNA extracted from the culture at three months p.i. and was still detectable by PCR at the time of writing (nine months p.i.). The Wolbachia wsp gene was also detectable by PCR in passages 1 and 2 at one month after subculture. The infected cells did not exhibit any cytopathic effects detectable by weekly inverted microscope examination. Intracellular bacteria were observed in Giemsa-stained cytocentrifuge smears prepared from the parent culture at eight months p.i., with approximately $25 \%$ of cells infected (Figure $4 a, b)$. To further characterise the bacterium isolated from the Malaysian cat fleas, fragments of the Wolbachia $\operatorname{cox} A, f b p A, f t s Z, h c p A$ and $g a t B$ genes were also amplified from DNA extracted from the parent infected IDE8 cell culture at 5 months p.i. The resultant sequences from the novel Wolbachia isolate, designated $w$ CfeF, were deposited in the NCBI GenBank database under accession numbers MT584103 (16S rRNA), MT577878 (coxA), MT577879 (fbpA), MT577880 (ftsZ), MT577881 (gatB) and MT577882 (hcpA), and compared with published sequences to determine its relationship with other Wolbachia strains.

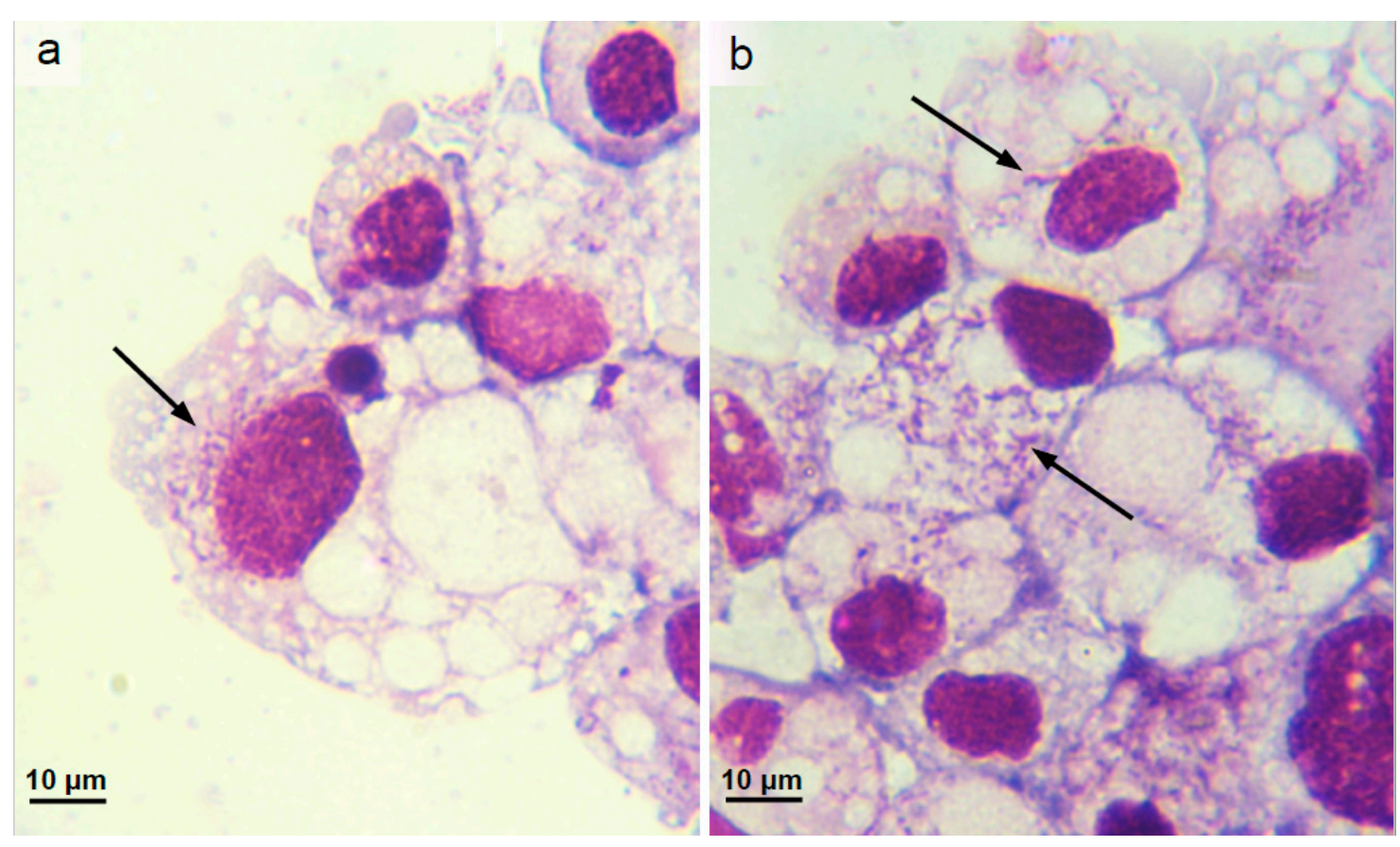

Figure 4. Ixodes scapularis cell line IDE8 infected with Wolbachia strain $w$ CfeF isolated from Malaysian Ctenocephalides sp. cat fleas. (a,b) Parent culture, 8 months after inoculation with flea organs; Giemsa-stained cytocentrifuge smears, arrows indicate infected cells.

A phylogenetic tree based on partial 16S rRNA sequences (Figure 5) positioned the $w$ CfeF isolate within the clade consisting of arthropod and filarial Wolbachia strains from the F supergroup (posterior probability $=100$ ). These include two Wolbachia strains previously identified in Ctenocephalides felis from Georgia, USA [15]. However, since only a short fragment of the 16S rRNA gene was used for phylogenetic construction, further investigation using additional gene sequences was necessary to determine its phylogenetic position. For this we used the concatenated and individual gene sets from the Wolbachia MLST scheme: fragments of the $\operatorname{cox} A, f b p A, f t s Z, h c p A$ and gatB genes [3]. The phylogeny of the concatenated MLST genes showed the clustering of $w \mathrm{CfeF}$ with Wolbachia strains from the F clade, including those from insects such as Supella longipalpa (Blattodea), Paratrechina longicornis (Hymenoptera) and Cimex lectularius (Hemiptera) (Figure 6a). Phylogenies based on individual genes showed similar positioning of $w \mathrm{CfeF}$ within the F clade (Figure $6 \mathrm{~b}-\mathrm{f}$ ). In these phylogenies, the current 
isolate appeared to be distinct from the other Wolbachia strains from C. felis that fall within other clades [26]. Altogether, the findings here support the placement of the $w \mathrm{CfeF}$ isolate within the F supergroup.

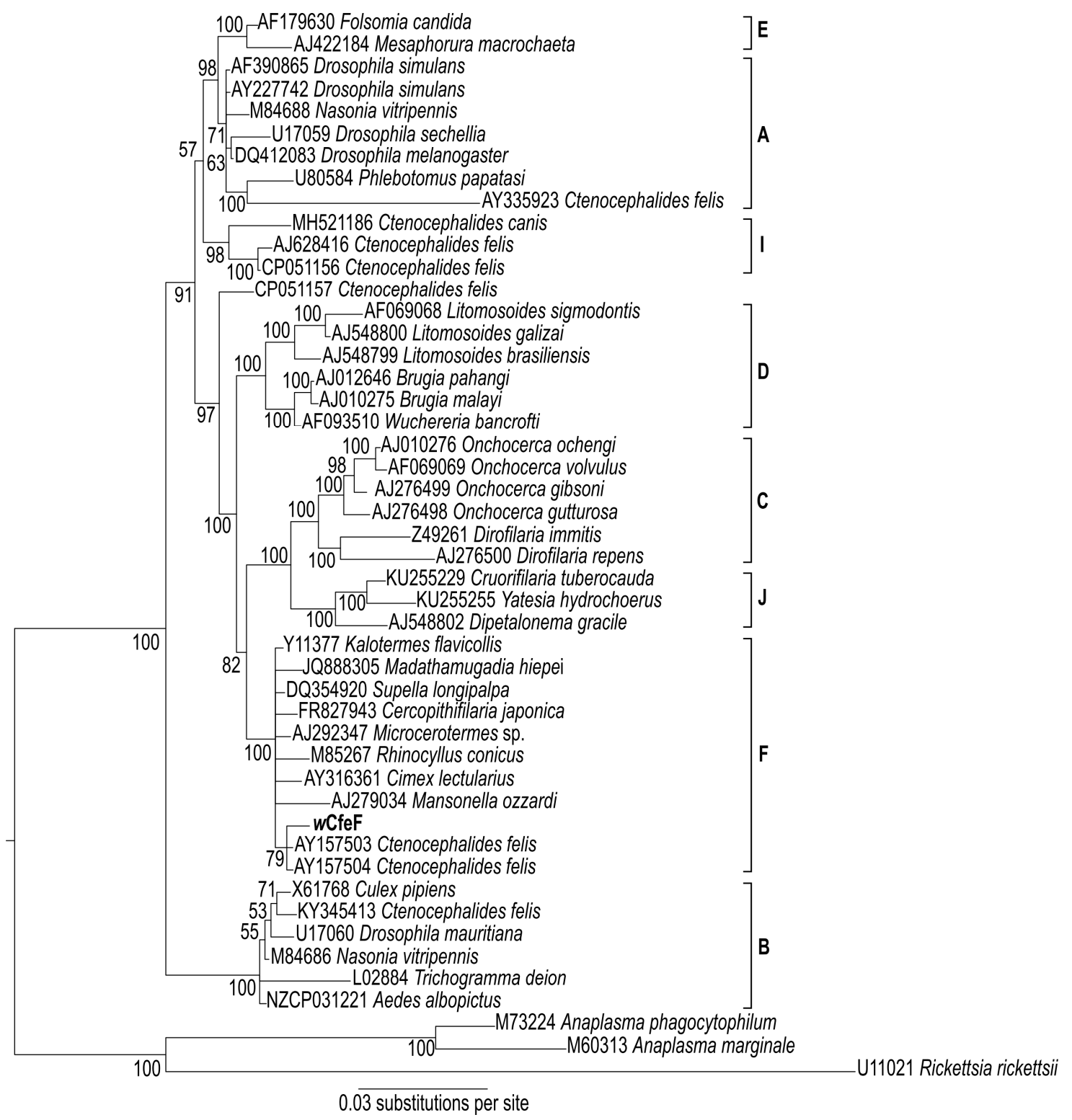

Figure 5. Bayesian inference phylogeny based on partial 16S rRNA sequences (1599 nucleotide positions) of novel Wolbachia strain $w \mathrm{CfeF}$ (in bold) isolated from Malaysian cat fleas, and of Wolbachia strains from the indicated hosts. Numbers at nodes represent Bayesian posterior probabilities (\%). Accession numbers are given for the sequences in the NCBI GenBank database. Other members of the Rickettsiales, Rickettsia rickettsii, Anaplasma phagocytophilum and Anaplasma marginale, were used as an outgroup. 
a

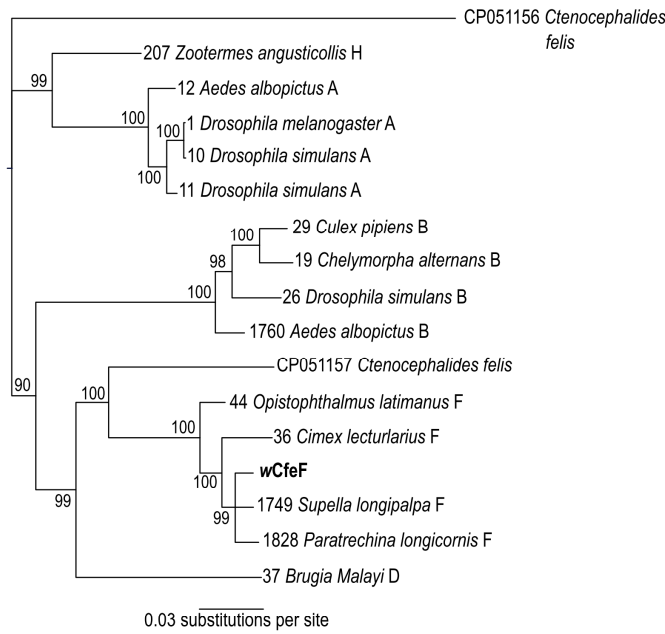

C
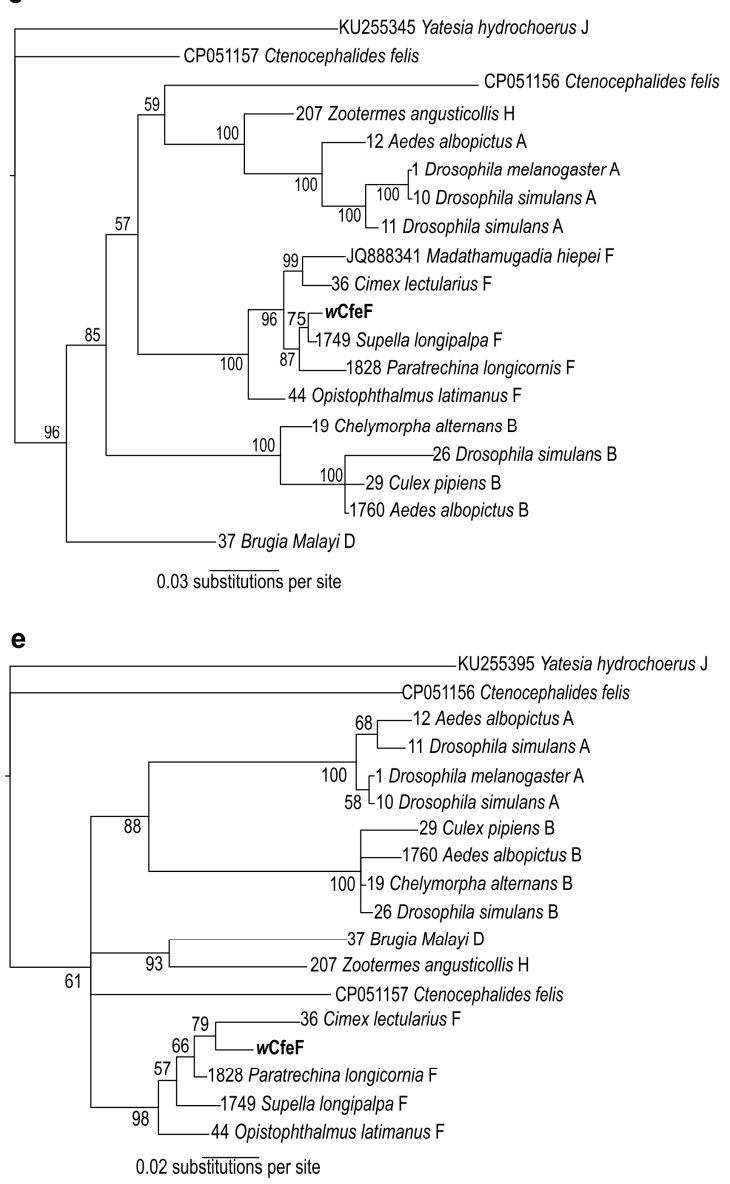

b

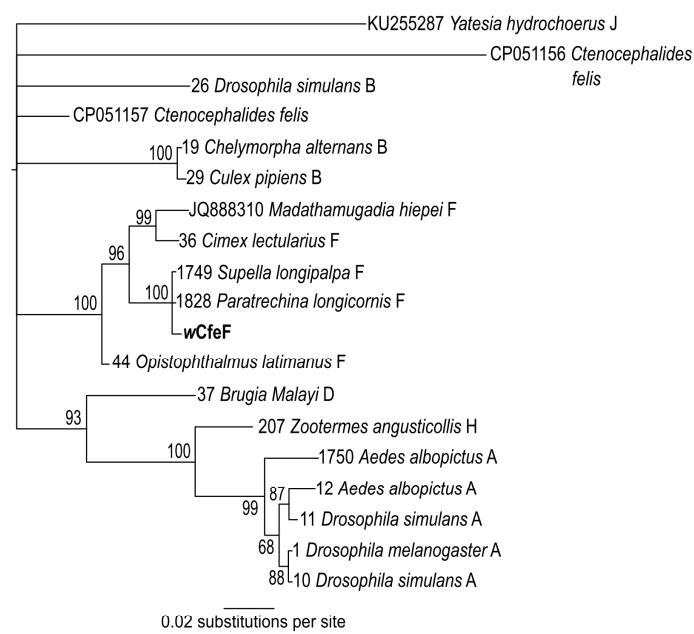

d

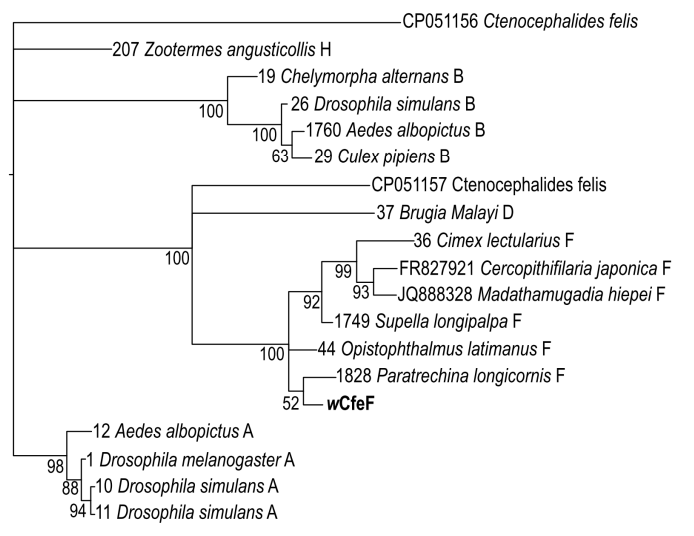

0.02 substitutions per site

f

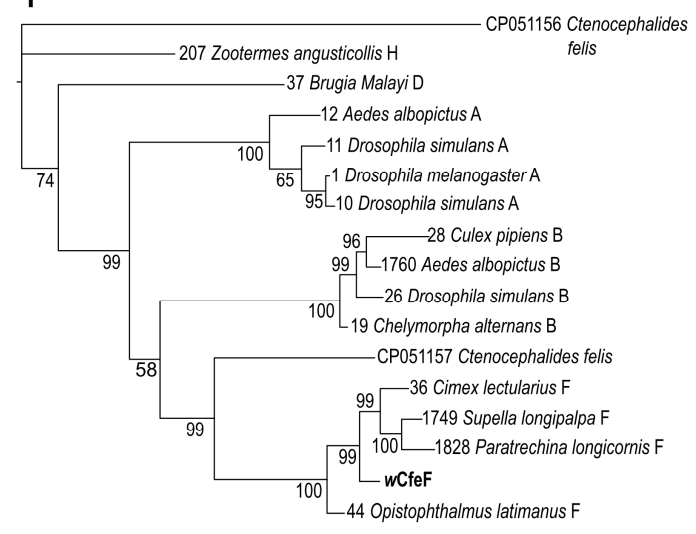

0.02 substitutions per site

Figure 6. Bayesian inference phylogeny based on concatenated and individual MSLT gene sequences of novel Wolbachia strain wCfeF (in bold) isolated from Malaysian cat fleas, and of Wolbachia strains from the indicated hosts. (a) Concatenated MLST genes (2082 nucleotide positions); (b) $\operatorname{cox} A$; (c) $f b p A$; (d) $f t s Z ; ~(e) ~ h c p A$; (f) gatB. Numbers at nodes represent Bayesian posterior probabilities (\%). Sample ID and accession numbers are given respectively for the sequences from the Wolbachia PubMLST and NCBI GenBank databases. 


\section{Discussion}

It is clear from our results that Wolbachia can invade and replicate in tick cells, at least in vitro. We demonstrated susceptibility of three cell lines derived from I. scapularis and one each from I. ricinus and R. microplus. Two laboratory-cultured strains and one novel field strain of Wolbachia, originating from diverse insect groups (mosquitoes, leafhoppers and fleas) and belonging to different supergroups (B and F), were able to infect and grow in tick cells. Special procedures, such as the shell vial technique or centrifugation, were not necessary for the initial infection of tick cells with Wolbachia, and infected cultures were maintained for long periods without the need for special incubation conditions. As seen in chronically-infected mosquito cell cultures $[69,72]$, tick cell cultures infected with Wolbachia strains $w \mathrm{AlbB}$ and $w \mathrm{CfeF}$ did not display any cytopathic effect over prolonged periods in vitro. In contrast, Ixodes spp. cultures heavily infected with the wStri strain displayed cytopathic effects, manifest as hypertrophied or pyknotic cells; the same strain in mosquito cells (AeAl-2) caused heavily infected cells to lose the ability to attach to a surface [56].

Considered together, all the tick cell lines used in the present study have previously been shown to be permissive for a wide range of intracellular bacteria transmitted and/or harboured by invertebrates. These include representatives of the genera Anaplasma [73,74], Cardinium [49,75], Ehrlichia [76-78], Neoehrlichia [79,80], Mycobacterium [81], Rickettsia [51,54,62,82-84] and Spiroplasma [62,85]. A previous study reported the propagation of a bacterium, then known as Wolbachia persica, in a Dermacentor albipictus tick cell line [86], but this bacterium was later found to belong to the genus Francisella [87]. Although the majority of these bacteria are tick-transmitted, exceptions include the predominantly flea-transmitted Rickettsia felis [83] and Mycobacterium leprae, the causative agent of leprosy, transmission of which may be associated with biting insects and ticks [81,88]. Tick cells similarly support the replication of a wide range of arboviruses transmitted not only by ticks but also by mosquitoes, sand flies and midges [89]. Therefore, it is not surprising that tick cell lines should be susceptible to infection with multiple strains of Wolbachia of insect origin. The ability of the novel Malaysian flea-derived Wolbachia isolate to infect and grow in a tick cell line confirmed the usefulness of tick cell lines in cultivating bacterial species of which ticks are not the natural hosts.

The cell lines used in the present study were also chosen because they belong to species in which Wolbachia has been detected by molecular techniques: I. scapularis [33,44], I. ricinus [34-36,38,43] and R. microplus $[37,41]$. Other tick species reported to harbour Wolbachia DNA include the ixodid ticks Amblyomma americanum [39], Rhipicephalus sanguineus [32], Dermacentor silvarum [45] and Haemaphysalis hystricis [40] and the argasid tick Ornithodoros rietcorreai [42]. None of these studies included a screen for insect DNA; concordance between the presence of Wolbachia and nematodes was not demonstrated [39]. To date, only two studies on I. ricinus $[47,48]$ have attempted to make the connection between Wolbachia and parasitic insects by screening samples for the presence of DNA from both bacteria and the parasitic wasp Ixodiphagus hookeri.

The intracellular morphology of the Wolbachia strains, as revealed in Giemsa-stained smears, was quite similar to that of other members of the Rickettsiales propagated in tick cell lines, such as Anaplasma marginale, Ehrlichia ruminantium, Neoehrlichia mikurensis and Rickettsia raoultii $[54,73,77,80]$. Purple-staining, pleomorphic bacteria were located singly or in small groups in the cytoplasm; no bacteria were seen in cell nuclei. The ultrastructural morphology of the wAlbB strain in BME/CTVM23 cells was more difficult to interpret. Readily-identifiable bacteria, such as those seen in $R$. raoultii-infected cells of the same line [54], were not obvious. Where bacteria could be identified, they were generally situated within large, membrane-bound vacuoles also occupied by a variety of structures commonly seen in electron micrographs of tick cells (lipid membrane whorls and vesicles of varying size and shape). The origin of the vesicles is unclear; the presence of secretory vesicles in vacuoles occupied by the wMelPop strain of Wolbachia in D. melanogaster brain cells was reported previously [71], and the authors speculated that these could have originated from the endoplasmic reticulum. However, in a detailed ultrastructural study of Wolbachia in B. malayi nematodes, immunogold labelling was used to show that vesicles found in association with Wolbachia were of bacterial origin [70]. 
Although over a dozen Wolbachia strains (including wStri, wAlbB and wMelPop) can be propagated continuously within insect cell culture systems, they belong exclusively to the more well-characterised A and B supergroups [69,72,90]. To the best of our knowledge, the new Malaysian Wolbachia strain is the only F supergroup member to be isolated into a cell line to date, the only flea-derived strain to be conclusively isolated and propagated over a prolonged period and the only Wolbachia field strain to be isolated into a tick cell line. A previous study did report the isolation of Wolbachia-like organisms from C. felis alongside Rickettsia felis in ISE6 cells; however, these putative Wolbachia were only identified morphologically and molecular confirmation was not presented [91].

The Wolbachia F supergroup is unique as members have been found in both arthropod and nematode hosts [92,93]. A previous study experimentally demonstrated a nutritional mutualism relationship between an F supergroup Wolbachia (wCle) and its host, the bedbug Cimex lectularius [20]. To the best of our knowledge, the only phenotypic data pertaining to Wolbachia infection in a flea was a comparison between laboratory and wild populations of the gerbil flea, Synosternus cleopatrae, that detected a negative impact of infection on reproductive success in the laboratory colony but not in the wild population [94]. Interestingly, the recent completion of the C. felis genome from a laboratory colony in California led to the generation of two complete Wolbachia genomes, neither of which was placed in supergroup F [26]. One of these genomes, designated wCfeT, contains a complete biotin synthesis operon and may be involved in providing nutrients to the host cell. The second genome, $w$ CfeJ, encodes a toxin-antidote system similar to that responsible for CI in dipteran hosts. However, experimental confirmation of mutualistic or parasitic roles for these Wolbachia in C. felis has not been published. The availability of a Wolbachia isolate from the F supergroup growing in a cell line will allow for further genetic and phenotypic characterisation at the cellular level, which could be useful in elucidating the Wolbachia-host relationship for this particular strain.

Despite the completion of the $C$. felis genome project and the detection of Wolbachia DNA in Ctenocephalides spp. fleas in several other studies [15,16,22,24,26], actual Wolbachia bacteria had not been visualised or isolated from fleas of this genus prior to the present study, although immunohistochemistry and transmission electron microscopy identified Wolbachia in the sand flea T. penetrans [14]. Sequence and phylogenetic analyses from separate studies suggest Ctenocephalides sp. fleas may not only host a wide range of Wolbachia strains from several distinct supergroups, but may also contain strains from a novel, divergent clade $[15,16,22,26,93]$. In Malaysia, DNA of Wolbachia from the B and F supergroups was detected in C. felis [22]; however, the sequences are not available in public databases for comparison with the novel $w$ CfeF isolate. The phylogenies of 16S rRNA and the MLST scheme genes provided compelling evidence for the placement of the $w \mathrm{CfeF}$ isolate within the F supergroup, similar to the Wolbachia strains previously reported from North American C. felis [15].

Reports of Wolbachia from Malaysia and the wider Southeast Asian region have primarily concerned the A and B supergroup Wolbachia from mosquitoes, owing to national research priorities placed on mosquito-borne diseases [95-97]. A number of studies also investigated the presence of Wolbachia in other insects, such as the tephritid fruit flies and the butterfly Hypolimnas bolina, as well as filarial nematodes including Brugia pahangi and Onchocerca borneensis [98-101]. The present study represents the first isolation and genetic characterisation of a Wolbachia strain from Ctenocephalides sp. fleas in this region.

The phylogenies from the concatenated genes and a subset of individual MLST genes (coxA, $f b p A$ and $f t s Z$ ) showed that $w$ CfeF appeared to be closely related to Wolbachia strains from the longhorn crazy ant P. longicornis, and the brown-banded cockroach S. longipalpa [102,103]. Results from a recent study suggested the occurrence of horizontal transfer of F group Wolbachia between Myrmecophilus spp. ant crickets and their ant hosts, including P. longicornis [102]. Currently, the infection events contributing to the occurrence of multiple Wolbachia strains in C. felis are still not fully understood, although it has been suggested that the predation of fleas by other insect species could be a possible mode of transmission between distantly-related hosts [20]. 
It is important to consider the possibility of there being more than one Wolbachia strain within the $w \mathrm{CfeF}$ culture since the starting inoculum consisted of organs from five individual fleas. Examination of our sequencing trace files revealed a small number of double peaks at several nucleotide positions in some amplicon sequences, suggesting the possibility of strain variations. However, the phylogenies based on the individual genes indicate that, even if more than one strain was present, they must be closely related as the placement of the novel strain $w \mathrm{CfeF}$ within the F clade was consistent across all tested loci. Further studies, including whole genome sequencing, should be carried out to verify the phylogenetic relationship between wCfeF and other Wolbachia strains, to establish the host cell range capable of supporting its in vitro propagation, and to determine its relationship with such host cells. Moreover, the taxonomy and population genetics of Ctenocephalides spp. in South-East Asia is complex, with two "tropical clusters" of C. felis as well as C. orientis (previously C.f. orientis) being found in the region [104]. Due to the emphasis on bacterial isolation from fresh material in the current study, detailed morphometric or molecular characterisation of the fleas was not attempted, but it is important to note that $C$. orientis has a strong host preference for dogs and, to a lesser extent, small ruminants [104,105]. Therefore, further studies are needed to determine the possible range of flea species and subspecific clades harbouring $w \mathrm{CfeF}$ in Malaysia and the wider South-East Asian region.

\section{Conclusions}

Tick cell lines can now be added to panels of insect, predominantly mosquito, cell lines to enhance the capability to isolate field strains of Wolbachia from naturally-infected arthropods. The ability to propagate Wolbachia continuously in tick cell lines provides a platform to examine how these bacteria might modulate the replication of tick-borne arboviruses, bacteria and protozoa, potentially leading to novel control strategies for tick-borne diseases. In light of our demonstration, that tick cells are capable of supporting long-term infection with Wolbachia, the exact nature of the relationship between the bacterium, ticks and other parasitic arthropods such as Ixodiphagus in the field should be re-examined.

Author Contributions: Conceptualization, J.J.K., T.J.K., G.L.H., S.A., B.L.M. and L.B.-S.; methodology, T.J.K. and L.B.-S.; formal analysis, J.J.K., A.B. and A.C.D.; investigation, J.J.K., T.J.K., N.A.H., F.S.L., M.M.S.Z., A.M.A.-K., C.H. and L.B.-S.; resources, T.J.K., A.C.D., B.L.M. and L.B.-S.; data curation, J.J.K., A.B. and A.C.D.; writing-original draft preparation, J.J.K., T.J.K., B.L.M. and L.B.-S.; writing—review and editing, J.J.K., T.J.K., A.B., C.H., A.C.D., G.L.H., B.L.M. and L.B.-S.; visualization, J.J.K., T.J.K., A.B., A.C.D. and B.L.M.; supervision, A.C.D., S.A., B.L.M. and L.B.-S.; project administration, J.J.K., T.J.K., B.L.M. and L.B.-S.; funding acquisition, T.J.K., S.A., B.L.M. All authors have read and agreed to the published version of the manuscript.

Funding: This research was supported by an Institutional Links grant, ID 332192305, under the Newton-Ungku Omar Fund partnership. The grant is funded by the UK Department of Business, Energy and Industrial Strategy (BEIS) and the Energy and Industrial Strategy and Malaysian Industry-Government Group for High Technology (MIGHT), and delivered by the British Council. Support was also provided by the UK BBSRC GCRF grants BB/P024270/1 and BB/P024378/1, and the Higher Institution Centre of Excellence (HICoE) program (Project MO002-2019), Ministry of Education, Malaysia for niche area research. TJK was supported by the University of Minnesota Agricultural Experiment Station. GLH was supported by UK BBSRC grant BB/T001240/1, a Royal Society Wolfson Fellowship (RSWF $\backslash$ R1 $\backslash 180013$ ), US NIH grants R21AI138074 and R21AI129507 and a UK NIHR grant NIHR2000907.

Acknowledgments: We would like to thank the Tick Cell Biobank for provision of some of the tick cell lines used in this work.

Conflicts of Interest: The authors declare no conflict of interest. The funders had no role in the design of the study; in the collection, analyses, or interpretation of data; in the writing of the manuscript, or in the decision to publish the results.

\section{References}

1. Hertig, M. The rickettsia, Wolbachia pipientis (gen. et sp.n.) and associated inclusions of the mosquito, Culex pipiens. Parasitology 1936, 28, 453-486. [CrossRef]

2. Zhou, W.; Rousset, F.; Neill, S.O. Phylogeny and PCR-based classification of Wolbachia strains using wsp gene sequences. Proc. R. Soc. Lond. B 1998, 265, 509-515. [CrossRef] 
3. Baldo, L.; Dunning Hotopp, J.C.; Jolley, K.A.; Bordenstein, S.R.; Biber, S.A.; Choudhury, R.R.; Hayashi, C.; Maiden, M.C.J.; Tettelin, H.; Werren, J.H. Multilocus sequence typing system for the endosymbiont Wolbachia pipientis. Appl. Environ. Microbiol. 2006, 72, 7098. [CrossRef] [PubMed]

4. Lefoulon, E.; Clark, T.; Borveto, F.; Perriat-Sanguinet, M.; Moulia, C.; Slatko, B.; Gavott, L. Pseudoscorpion Wolbachia symbionts: Diversity and evidence for a new supergroup S. BMC Microbiol. 2020, 20, 188. [CrossRef]

5. Chung, M.; Munro, J.B.; Tettelin, H.; Hotopp, J.C.D. Using core genome alignments to assign bacterial species. Ecol. Evol. Sci. 2018, 3, e00236-18. [CrossRef]

6. Weeks, A.R.; Breeuwer, J.A.J. Wolbachia-induced parthenogenesis in a genus of phytophagous mites. Proc. R. Soc. Lond. B 2001, 268, 2245-2251. [CrossRef] [PubMed]

7. Hornett, E.A.; Duplouy, A.M.R.; Davies, N.; Roderick, G.K.; Wedell, N.; Hurst, G.D.D.; Charlat, S. You can't keep a good parasite down: Evolution of a male-killer suppressor uncovers cytoplasmic incompatibility. Evolution 2008, 62, 1258-1263. [CrossRef]

8. Werren, J.H.; Baldo, L.; Clark, M.E. Wolbachia: Master manipulators of invertebrate biology. Nat. Rev. Microbiol. 2008, 6, 741-751. [CrossRef]

9. Kern, P.; Cook, J.M.; Kageyama, D.; Riegler, M. Double trouble: Combined action of meiotic drive and Wolbachia feminization in Eurema butterflies. Biol. Lett. 2015, 11, 20150095. [CrossRef]

10. Gerth, M.; Gansauge, M.-T.; Weigert, A.; Bleidorn, C. Phylogenomic analyses uncover origin and spread of the Wolbachia pandemic. Nat. Commun. 2014, 5, 5117. [CrossRef]

11. Weinert, L.A.; Araujo-Jnr, E.V.; Ahmed, M.Z.; Welch, J.J. The incidence of bacterial endosymbionts in terrestrial arthropods. Proc. R. Soc. B 2015, 282, 20150249. [CrossRef] [PubMed]

12. Fenn, K.; Blaxter, M. Wolbachia genomes: Revealing the biology of parasitism and mutualism. Trends Parasitol. 2006, 22, 60-65. [CrossRef]

13. Pike, N.; Kingcombe, R. Antibiotic treatment leads to the elimination of Wolbachia endosymbionts and sterility in the diplodiploid collembolan Folsomia candida. BMC Biol. 2009, 7, 54. [CrossRef]

14. Fischer, P.; Schmetz, C.; Bandi, C.; Bonow, I.; Mand, S.; Fischer, K.; Büttner, D.W. Tunga penetrans: Molecular identification of Wolbachia endobacteria and their recognition by antibodies against proteins of endobacteria from filarial parasites. Exp. Parasitol. 2002, 102, 201-211. [CrossRef]

15. Gorham, C.; Fang, Q.; Durden, L. Wolbachia endosymbionts in fleas (Siphonaptera). J. Parasitol. 2003, 89, 283-289. [CrossRef]

16. Dittmar, K.; Whiting, M. New Wolbachia endosymbiont from Nearctic and Neotropical fleas (Siphonaptera). J. Parasitol. 2004, 90, 953-957. [CrossRef] [PubMed]

17. Kyei-Poku, G.K.; Colwell, D.D.; Coghlin, P.; Benkel, B.; Floate, K.D. On the ubiquity and phylogeny of Wolbachia in lice. Mol. Ecol. 2005, 14, 285-294. [CrossRef]

18. Espino, C.I.; Gomez, T.; Gonzalez, G.; Brazil do Santos, M.F.; Solano, J.; Sousa, O.; Moreno, N.; Windsor, D.; Ying, A.; Vilchez, S.; et al. Detection of Wolbachia bacteria in multiple organs and feces of the triatomine insect Rhodnius pallescens (Hemiptera, Reduviidae). Appl. Environ. Microbiol. 2009, 75, 547-550. [CrossRef]

19. Crainey, J.L.; Wilson, M.D.; Post, R.J. Phylogenetically distinct Wolbachia gene and pseudogene sequences obtained from the African onchocerciasis vector Simulium squamosum. Int. J. Parasitol. 2010, 40, 569-578. [CrossRef]

20. Hosokawa, T.; Koga, R.; Kikuchi, Y.; Meng, X.-Y.; Fukatsu, T. Wolbachia as a bacteriocyte-associated nutritional mutualist. Proc. Natl. Acad. Sci. USA 2010, 107, 769-774. [CrossRef]

21. Doudoumis, V.; Alam, U.; Aksoy, E.; Abd-Alla, A.M.M.; Tsiamis, G.; Brelsfoard, C.; Aksoy, S.; Bourtzis, K. Tsetse-Wolbachia symbiosis: Comes of age and has great potential for pest and disease control. J. Invertebr. Pathol. 2013, 112, S94-S103. [CrossRef] [PubMed]

22. Tay, S. Wolbachia endosymbionts, Rickettsia felis and Bartonella species, in Ctenocephalides felis fleas in a tropical region. J. Vector Ecol. 2013, 38, 200-202. [CrossRef] [PubMed]

23. Kittipong, C.; McGarry, J.W.; Morand, S.; Makepeace, B.L. Symbiosis in an overlooked microcosm: A systematic review of the bacterial flora of mites. Parasitology 2015, 142, 1152-1162. [CrossRef]

24. Onder, Z.; Ciloglu, A.; Duzlu, O.; Yildirim, A.; Okur, M.; Yetismis, G.; Inci, A. Molecular detection and identification of Wolbachia endosymbiont in fleas (Insecta: Siphonaptera). Folia Microbiol. 2019, 64, 789-796. [CrossRef] [PubMed]

25. Sicard, M.; Bonneau, M.; Weill, M. Wolbachia prevalence, diversity, and ability to induce cytoplasmic incompatibility in mosquitoes. Curr. Opin. Insect Sci. 2019, 34, 12-20. [CrossRef] 
26. Driscoll, T.P.; Verhoeve, V.I.; Gillespie, J.J.; Johnston, J.S.; Guillotte, M.L.; Rennoll-Bankert, K.E.; Rahman, M.S.; Hagen, D.; Elsik, C.G.; Macaluso, K.R.; et al. A chromosome-level assembly of the cat flea genome uncovers rampant gene duplication and genome size plasticity. BMC Biol. 2020, 18, 70. [CrossRef]

27. Yen, J.H.; Barr, A.R. New hypothesis of the cause of cytoplasmic incompatibility in Culex pipiens L. Nature 1971, 232, 657-658. [CrossRef]

28. Bourtzis, K.; Dobson, S.L.; Xi, Z.; Rasgon, J.L.; Calvitti, M.; Moreira, L.A.; Bossin, H.C.; Moretti, R.; Baton, L.A.; Hughes, G.L.; et al. Harnessing mosquito-Wolbachia symbiosis for vector and disease control. Acta Trop. 2014, 132, S150-S163. [CrossRef]

29. Bouchery, T.; Lefoulon, E.; Karadjian, G.; Nieguitsila, A.; Martin, C. The symbiotic role of Wolbachia in Onchocercidae and its impact on filariasis. Clin. Microbiol. Infect. 2013, 19, 131-140. [CrossRef]

30. Hughes, G.L.; Rasgon, J.L. Transinfection: A method to investigate Wolbachia-host interactions and control arthropod-borne disease. Insect Mol. Biol. 2014, 23, 141-151. [CrossRef]

31. Kamtchum-Tatuene, J.; Makepeace, B.L.; Benjamin, L.; Baylis, M.; Solomon, T. The potential role of Wolbachia in controlling the transmission of emerging human arboviral infections. Curr. Opin. Infect. Dis. 2017, 30, 108-116. [CrossRef] [PubMed]

32. Inokuma, H.; Raoult, D.; Brouqui, P. Detection of Ehrlichia platys DNA in brown dog ticks (Rhipicephalus sanguineus) in Okinawa Island, Japan. J. Clin. Microbiol. 2000, 38, 4219-4221. [CrossRef] [PubMed]

33. Benson, M.J.; Gawronski, J.D.; Eveleigh, D.E.; Benson, D.R. Intracellular symbionts and other bacteria associated with deer ticks (Ixodes scapularis) from Nantucket and Wellfleet, Cape Cod, Massachusetts. Appl. Environ. Microbiol. 2004, 70, 616-620. [CrossRef]

34. Hartelt, K.; Oehme, R.; Frank, H.; Brockmann, S.O.; Hassler, D.; Kimmig, P. Pathogens and symbionts in ticks: Prevalence of Anaplasma phagocytophilum (Ehrlichia sp.), Wolbachia sp., Rickettsia sp., and Babesia sp. in Southern Germany. Int. J. Med. Microbiol. 2004, 293 (Suppl. S37), 86-92. [CrossRef]

35. Sarih, M.; M'Ghirbi, Y.; Bouattour, A.; Gern, L.; Baranton, G.; Postic, D. Detection and identification of Ehrlichia spp. in ticks collected in Tunisia and Morocco. J. Clin. Microbiol. 2005, 43, 1127-1132. [CrossRef] [PubMed]

36. van Overbeek, L.; Gassner, L.; van der Plas, C.L.; Kastelein, P.; Nunes-da Rocha, U.; Takken, W. Diversity of Ixodes ricinus tick-associated bacterial communities from different forests. FEMS Microbiol. Ecol. 2008, 66, 72-84. [CrossRef]

37. Andreotti, R.; de Leon, A.A.P.; Dowd, S.E.; Guerrero, F.D.; Bendele, K.G.; Scoles, G.A. Assessment of bacterial diversity in the cattle tick Rhipicephalus (Boophilus) microplus through tag-encoded pyrosequencing. BMC Microbiol. 2011, 11, 6. [CrossRef]

38. Carpi, G.; Cagnacci, F.; Wittenkindt, N.E.; Zhao, F.; Qi, J.; Tomsho, L.P.; Drautz, D.I.; Rizzoli, A.; Schuster, S.C. Metagenomic profile of the bacterial communities associated with Ixodes ricinus ticks. PLoS ONE 2011, 6, e25604. [CrossRef]

39. Zhang, X.; Norris, D.E.; Rasgon, J.L. Distribution and molecular characterization of Wolbachia endosymbionts and filarial nematodes in Maryland populations of the lone star tick (Amblyomma americanum). FEMS Microbiol. Ecol. 2011, 77, 50-56. [CrossRef]

40. Khoo, J.-J.; Chen, F.; Kho, K.L.; Shanizza, A.I.A.; Lim, F.-S.; Tan, K.-K.; Chang, L.-Y.; AbuBakar, S. Bacterial community in Haemaphysalis ticks of domesticated animals from the Orang Asli communities in Malaysia. Ticks Tick Borne Dis. 2016, 7, 929-937. [CrossRef]

41. Hirunkanokpun, S.; Ahantarig, A.; Baimai, V.; Trinachartvanit, W. A new record of Wolbachia in the elephant ticks from Thailand. ScienceAsia 2018, 44S, 44-47. [CrossRef]

42. Muñoz-Leal, S.; Macedo, C.; Gonçalves, T.C.; Barreira, J.D.; Labruna, M.B.; Sampaio de Lemos, E.R.; Ogrzewalska, M. Detected microorganisms and new geographic records of Ornithodoros rietcorreai (Acari: Argasidae) from northern Brazil. Ticks Tick Borne Dis. 2019, 10, 853-861. [CrossRef] [PubMed]

43. Nebbak, A.; Dahmana, H.; Almeeras, L.; Raoult, D.; Boulanger, N.; Jaulhac, B.; Mediannikov, O.; Parola, P. Co-infection of bacteria and protozoan parasites in Ixodes ricinus nymphs collected in the Alsace region, France. Ticks Tick Borne Dis. 2019, 10, 101241. [CrossRef] [PubMed]

44. Thapa, S.; Zhang, Y.; Allen, M.S. Bacterial microbiomes of Ixodes scapularis ticks collected from Massachusetts and Texas, USA. BMC Microbiol. 2019, 19, 138. [CrossRef] [PubMed]

45. Duan, D.-Y.; Liu, G.-H.; Cheng, T.-Y. Microbiome analysis of the saliva and midgut from partially or fully engorged female adult Dermacentor silvarum ticks in China. Exp. Appl. Acarol. 2020, 80, 543-558. [CrossRef] 
46. Hu, R.; Hyland, K.E.; Oliver, J.H., Jr. A review on the use of Ixodiphagus wasps (Hymenoptera: Encyrtidae) as natural enemies for the control of ticks (Acari: Ixodidae). Syst. Appl. Acarol. 1998, 3, 19-28. [CrossRef]

47. Tijsse-Klasen, E.; Braks, M.; Scholte, E.-J.; Sprong, H. Parasites of vectors-Ixodiphagus hookeri and its Wolbachia symbionts in ticks in The Netherlands. Parasites Vectors 2011, 4, 228. [CrossRef]

48. Plantard, O.; Bouju-Albert, A.; Malard, M.-A.; Hermouet, A.; Capron, G.; Verheyden, H. Detection of Wolbachia in the tick Ixodes ricinus is due to the presence of the Hymenoptera endoparasitoid Ixodiphagus hookeri. PLoS ONE 2012, 7, e30692. [CrossRef]

49. Kurtti, T.J.; Munderloh, U.G.; Andreadis, T.G.; Magnarelli, L.A.; Mather, T.N. Tick cell culture isolation of an intracellular prokaryote from the tick Ixodes scapularis. J. Invert. Pathol. 1996, 67, 318-321. [CrossRef]

50. Munderloh, U.G.; Liu, Y.; Wang, M.; Chen, C.; Kurtti, T.J. Establishment, maintenance and description of cell lines from the tick Ixodes scapularis. J. Parasitol. 1994, 80, 533-543. [CrossRef]

51. Simser, J.A.; Palmer, A.T.; Fingerle, V.; Wilske, B.; Kurtti, T.J.; Munderloh, U.G. Rickettsia monacensis sp. nov., a spotted fever group rickettsia, from ticks (Ixodes ricinus) collected in a European city park. Appl. Environ. Microbiol. 2002, 68, 4559-4566. [CrossRef] [PubMed]

52. Oliver, J.D.; Burkhardt, N.Y.; Felsheim, R.F.; Kurtti, T.L.; Munderloh, U.G. Motility characteristics are altered for Rickettsia bellii transformed to overexpress a heterologous rickA gene. Appl. Environ. Microbiol. 2014, 80, 1170-1176. [CrossRef] [PubMed]

53. Munderloh, U.G.; Kurtti, T.J. Formulation of medium for tick cell culture. Exp. Appl. Acarol. 1989, 7, $219-229$. [CrossRef]

54. Alberdi, M.P.; Nijhof, A.M.; Jongejan, F.; Bell-Sakyi, L. Tick cell culture isolation and growth of Rickettsia raoultii from Dutch Dermacentor reticulatus ticks. Ticks Tick Borne Dis. 2012, 3, 349-354. [CrossRef]

55. Mitsuhashi, J. A new continuous cell line from larvae of the mosquito Aedes albopictus (Diptera, Culicidae). Biomed. Res. 1981, 2, 599-606. [CrossRef]

56. Noda, H.; Miyoshi, T.; Koizumi, Y. In vitro cultivation of Wolbachia in insect and mammalian cell lines. In Vitro Cell. Dev. Biol. Anim. 2002, 38, 423-427. [CrossRef]

57. O'Neill, S.L.; Pettigrew, M.M.; Sinkins, S.P.; Braig, H.R.; Andreadis, T.G.; Tesh, R.B. In vitro cultivation of Wolbachia pipientis in Aedes albopictus cell line. Insect Mol. Biol. 1997, 6, 33-39. [CrossRef]

58. Igarashi, A. Isolation of a Singh's Aedes albopictus cell clone sensitive to Dengue and Chikungunya viruses. J. Gen. Virol. 1978, 40, 531-544. [CrossRef]

59. Kurtti, T.J.; Burkhardt, N.Y.; Heu, C.C.; Munderloh, U.G. Fluorescent protein expressing Rickettsia buchneri and Rickettsia peacockii for tracking symbiont-tick interactions. Vet. Sci. 2016, 3, 34. [CrossRef]

60. Pratt, H.; Stojanovich, C. Fleas: Illustrated Key to Species Found During Plague Investigations. In CDC Pictorial Keys, Arthropods, Reptiles, Birds and Mammals of Public Health Significance; US Department of Health Education and Welfare, Public Health Service, Communicable Disease Center: Atlanta, GA, USA, 1966; pp. 171-174.

61. Bell-Sakyi, L.; Mohd Jaafar, F.; Monsion, B.; Luu, L.; Denison, E.; Carpenter, S.; Attoui, H.; Mertens, P.P.C. Continuous cell lines from the European biting midge Culicoides nubeculosus (Meigen, 1830). Microorganisms 2020, 8, 825. [CrossRef]

62. Palomar, A.M.; Premchand-Branker, S.; Alberdi, P.; Belova, O.; Moniuszko-Malinowska, A.; Kahl, O.; Bell-Sakyi, L. Isolation of known and potentially pathogenic tick-borne microorganisms from European ixodid ticks using tick cell lines. Ticks Tick Borne Dis. 2019, 10, 628-638. [CrossRef]

63. Makepeace, B.L.; Rodgers, L.; Trees, A.J. Rate of elimination of Wolbachia pipientis by doxycycline in vitro increases following drug withdrawal. Antimicrob. Agents Chemother. 2006, 50, 922-927. [CrossRef] [PubMed]

64. Al-Khafaji, A.M.; Clegg, S.R.; Pinder, A.C.; Luu, L.; Hansford, K.M.; Seelig, F.; Dinnis, R.E.; Margos, G.; Medlock, J.M.; Feil, E.J.; et al. Multi-locus sequence typing of Ixodes ricinus and its symbiont Candidatus Midichloria mitochondrii across Europe reveals evidence of local co-cladogenesis in Scotland. Ticks Tick Borne Dis. 2019, 10, 52-62. [CrossRef] [PubMed]

65. Sievers, F.; Wilm, A.; Dineen, D.; Gibson, T.J.; Karplus, K.; Li, W.; Lopez, R.; McWilliam, H.; Remmert, M.; Söding, J. Fast, scalable generation of high-quality protein multiple sequence alignments using Clustal Omega. Molec. Syst. Biol. 2011, 7, 539. [CrossRef] [PubMed]

66. Wolbachia MLST Databases. Available online: https://pubmlst.org/wolbachia/ (accessed on 8 April 2020). 
67. Ronquist, F.; Teslenko, M.; Van Der Mark, P.; Ayres, D.L.; Darling, A.; Höhna, S.; Larget, B.; Liu, L.; Suchard, M.A.; Huelsenbeck, J.P. MrBayes 3.2: Efficient Bayesian phylogenetic inference and model choice across a large model space. Syst. Biol. 2012, 61, 539-542. [CrossRef]

68. Posada, D. Jmodeltest: Phylogenetic model averaging. Molec. Biol. Evol. 2008, 25, 1253-1256. [CrossRef]

69. McMeniman, C.J.; Lane, A.M.; Fong, A.W.C.; Voronin, D.A.; Iturbe-Ormaetxe, I.; Yamada, R.; McGraw, E.A.; O'Neill, S.L. Host adaptation of a Wolbachia strain after long-term serial passage in mosquito cell lines. Appl. Environ. Microbiol. 2008, 74, 6963. [CrossRef]

70. Fischer, K.; Beatty, W.L.; Weil, G.J.; Fischer, P.U. High pressure freezing/freeze substitution fixation improves the ultrastructural assessment of Wolbachia endosymbiont-filarial nematode host interaction. PLoS ONE 2014, 9, e86383. [CrossRef]

71. Strunov, A.; Kiseleva, E. Drosophila melanogaster brain invasion: Pathogenic Wolbachia in central nervous system of the fly. Insect Sci. 2016, 23, 253-264. [CrossRef]

72. Fallon, A.M.; Baldridge, G.D.; Higgins, L.A.; Witthuhn, B.A. Wolbachia from the planthopper Laodelphax striatellus establishes a robust, persistent, streptomycin-resistant infection in clonal mosquito cells. In Vitro Cell. Dev. Biol. Anim. 2013, 49, 66-73. [CrossRef]

73. Munderloh, U.G.; Blouin, E.F.; Kocan, K.M.; Ge, N.L.; Edwards, W.L.; Kurtti, T.J. Establishment of the tick (Acari: Ixodidae)-borne cattle pathogen Anaplasma marginale (Rickettsiales: Anaplasmataceae) in tick cell culture. J. Med. Entomol. 1996, 33, 656-664. [CrossRef]

74. Munderloh, U.G.; Jauron, S.D.; Fingerle, V.; Leitritz, L.; Hayes, S.F.; Hautman, J.M.; Nelson, C.M.; Huberty, B.W.; Kurtti, T.J.; Ahlstrand, G.G.; et al. Invasion and intracellular development of the human granulocytic ehrlichiosis agent in tick cell culture. J. Clin. Microbiol. 1999, 37, 2518-2524. [CrossRef]

75. Morimoto, S.; Kurtti, T.J.; Noda, H. In vitro cultivation and antibiotic susceptibility of a Cytophaga-like intracellular symbiote isolated from the tick Ixodes scapularis. Curr. Microbiol. 2006, 52, 324-329. [CrossRef] [PubMed]

76. Ewing, S.A.; Munderloh, U.G.; Blouin, E.F.; Kocan, K.M.; Kurtti, T.J. Ehrlichia canis in tick cell culture. In Proceedings of the 76th Conference of Research Workers in Animal Diseases, Chicago, IL, USA, 13-14 November 1995; Iowa State University Press: Ames, IA, USA, 1995. abstract no. 165.

77. Bell-Sakyi, L.; Paxton, E.A.; Munderloh, U.G.; Sumption, K.J. Growth of Cowdria ruminantium, the causative agent of heartwater, in a tick cell line. J. Clin. Microbiol. 2000, 38, 1238-1240. [CrossRef] [PubMed]

78. Ferrolho, J.; Simpson, J.; Hawes, P.; Zweygarth, E.; Bell-Sakyi, L. Growth of Ehrlichia canis, the causative agent of canine monocytic ehrlichiosis, in vector and non-vector ixodid tick cell lines. Ticks Tick Borne Dis. 2016, 7, 631-637. [CrossRef]

79. Munderloh, U.G.; Yabsley, M.J.; Murphy, S.M.; Luttrell, M.P.; Howerth, E.W. Isolation and establishment of the raccoon Ehrlichia-like agent in tick cell culture. Vector-Borne Zoonot. Dis. 2007, 7, 418-425. [CrossRef]

80. Wass, L.; Grankvist, A.; Bell-Sakyi, L.; Bergström, M.; Ulfhammer, E.; Lingblom, C.; Wennerås, C. Cultivation of the causative agent of human neoehrlichiosis from clinical isolates identifies vascular endothelium as a target of infection. Emerg. Microbes Infect. 2019, 8, 413-425. [CrossRef]

81. Ferreira, J.S.; Oliveira, D.A.S.; Santos, J.P.; Ribeiro, C.C.D.U.; Baêta, B.A.; Teixeira, R.C.; Neumann, A.S.; Rosa, P.S.; Pessolani, M.C.V.; Moraes, M.O.; et al. Ticks as potential vectors of Mycobacterium leprae: Use of tick cell lines to culture the bacilli and generate transgenic strains. PLoS Negl. Trop. Dis. 2018, 12, e0007001. [CrossRef]

82. Kurtti, T.J.; Simser, J.A.; Baldridge, G.D.; Palmer, A.T.; Munderloh, U.G. Factors influencing in vitro infectivity and growth of Rickettsia peacockii (Rickettsiales: Rickettsiaceae), an endosymbiont of the Rocky Mountain wood tick, Dermacentor andersoni (Acari, Ixodidae). J. Invert. Pathol. 2005, 90, 177-186. [CrossRef]

83. Pornwiroon, W.; Pourciau, S.S.; Foil, L.D.; Macaluso, K.R. Rickettsia felis from cat fleas: Isolation and culture in a tick-derived cell line. Appl. Environ. Microbiol. 2006, 72, 5589-5595. [CrossRef]

84. Kurtti, T.J.; Felsheim, R.F.; Burkhardt, N.Y.; Oliver, J.D.; Heu, C.C.; Munderloh, U.G. Rickettsia buchneri sp. nov., a rickettsial endosymbiont of the blacklegged tick Ixodes scapularis. Int. J. Syst. Evol. Microbiol. 2015, 65, 965-970. [CrossRef] [PubMed]

85. Bell-Sakyi, L.; Palomar, A.M.; Kazimirova, M. Isolation and propagation of a Spiroplasma sp. from Slovakian Ixodes ricinus ticks in Ixodes spp. cell lines. Ticks Tick Borne Dis. 2015, 6, 601-606. [CrossRef] [PubMed] 
86. Noda, H.; Munderloh, U.G.; Kurtti, T.J. Endosymbionts of ticks and their relationship to Wolbachia spp. and tick-borne pathogens of humans and animals. Appl. Environ. Microbiol. 1997, 63, 3926-3932. [CrossRef] [PubMed]

87. Larson, M.A.; Nalbantoglu, U.; Sayood, K.; Zentz, E.B.; Cer, R.Z.; Iwen, P.C.; Francesconi, S.C.; Bishop-Lilly, K.A.; Mokashi, V.P.; Sjöstedt, A.; et al. Reclassification of Wolbachia persica as Francisella persica comb. nov. and emended description of the family Francisellaceae. Int. J. Syst. Evol. Microbiol. 2016, 66, 1200-1205. [CrossRef] [PubMed]

88. Neumann, A.S.; Dias, F.A.; Ferreira, J.S.; Fontes, A.N.B.; Rosa, P.S.; Macedo, R.E.; Oliveira, J.H.; Texeira, R.L.F.; Pessolani, M.C.V.; Moraes, M.O.; et al. Experimental infection of Rhodnius prolixus (Hemiptera, Triatominae) with Mycobacterium leprae indicates potential for leprosy transmission. PLoS ONE 2016, 11, e0156037. [CrossRef]

89. Bell-Sakyi, L.; Kohl, A.; Bente, D.A.; Fazakerley, J.F. Tick cell lines for study of Crimean-Congo hemorrhagic fever virus and other arboviruses. Vector-Borne Zoonot. Dis. 2012, 12, 769-781. [CrossRef]

90. Lu, P.; Bian, G.; Pan, X.; Xi, Z. Wolbachia induces density-dependent inhibition to dengue virus in mosquito cells. PLoS Negl. Trop. Dis. 2012, 6, e1754. [CrossRef]

91. Sunyakumthorn, P.; Bourchookarn, A.; Pornwiroon, W.; David, C.; Barker, S.A.; Macaluso, K.R. Characterization and growth of polymorphic Rickettsia felis in a tick cell line. Appl. Environ. Microbiol. 2008, 74, 3151-5158. [CrossRef]

92. Casiraghi, M.; Bordenstein, S.R.; Baldo, L.; Lo, N.; Beninati, T.; Wernegreen, J.J.; Werren, J.H.; Bandi, C. Phylogeny of Wolbachia pipientis based on glta, groel and ftsz gene sequences: Clustering of arthropod and nematode symbionts in the F supergroup, and evidence for further diversity in the Wolbachia tree. Microbiology 2005, 151, 4015-4022. [CrossRef]

93. Ferri, E.; Bain, O.; Barbuto, M.; Martin, C.; Lo, N.; Uni, S.; Landmann, F.; Baccei, S.G.; Guerrero, R.; de Souza Lima, S.; et al. New insights into the evolution of Wolbachia infections in filarial nematodes inferred from a large range of screened species. PLOS ONE 2011, 6, e20843. [CrossRef]

94. Flatau, R.; Segoli, M.; Khokhlova, I.; Hawlena, H. Wolbachia's role in mediating its flea's reproductive success differs according to flea origin. FEMS Microbiol. Ecol. 2018, 94, fiy157. [CrossRef] [PubMed]

95. Ahantarig, A.; Trinachartvanit, W.; Kittayapong, P. Relative Wolbachia density of field-collected Aedes albopictus mosquitoes in Thailand. J. Vector Ecol. 2008, 33, 173-177. [CrossRef]

96. Ahmad, N.A.; Vythilingam, I.; Lim, Y.A.L.; Zabari, N.Z.A.M.; Lee, H.L. Detection of Wolbachia in Aedes albopictus and their effects on Chikungunya virus. Am. J. Trop. Med. Hyg. 2017, 96, 148-156. [CrossRef] [PubMed]

97. Carvajal, T.M.; Hashimoto, K.; Harnandika, R.K.; Amalin, D.M.; Watanabe, K. Detection of Wolbachia in field-collected Aedes aegypti mosquitoes in metropolitan Manila, Philippines. Parasites Vectors 2019, 12, 361. [CrossRef] [PubMed]

98. Kittayapong, P.; Milne, J.R.; Tigvattananont, S.; Baimai, V. Distribution of the reproduction-modifying bacteria, Wolbachia, in natural populations of tephritid fruit flies in Thailand. ScienceAsia 2000, 26, 93-103. [CrossRef]

99. Charlat, S.; Hornett, E.A.; Dyson, E.A.; Ho, P.P.Y.; Loc, N.T.; Schilthuizen, M.; Davies, N.; Roderick, G.K.; Hurst, G.D.D. Prevalence and penetrance variation of male-killing Wolbachia across Indo-Pacific populations of the butterfly Hypolimnas bolina. Molec. Ecol. 2005, 14, 3525-3530. [CrossRef] [PubMed]

100. Lau, Y.-L.; Lee, W.-C.; Xia, J.; Zhang, G.; Razali, R.; Anwar, A.; Fong, M.-Y. Draft genome of Brugia pahangi: High similarity between B. pahangi and B. malayi. Parasites Vectors 2015, 8, 451. [CrossRef]

101. Uni, S.; Mat Udin, A.S.; Agatsuma, T.; Junker, K.; Saijuntha, W.; Bunchom, N.; Fukuda, M.; Martin, C.; Lefoulon, E.; Labat, A.; et al. Description, molecular characteristics and Wolbachia endosymbionts of Onchocerca borneensis Uni, Mat Udin \& Takaoka n. sp. (Nematoda: Filarioidea) from the Bornean bearded pig Sus barbatus Müller (Cetartiodactyla: Suidae) of Sarawak, Malaysia. Parasites Vectors 2020, 13, 50. [CrossRef]

102. Tseng, S.; Hsu, P.; Lee, C.; Wetterer, J.K.; Hugel, S.K.; Wu, L.; Lee, C.; Yoshimura, T.; Yang, C.S. Evidence for common horizontal transmission of Wolbachia among ants and ant crickets: Kleptoparasitism added to the list. Microorganisms 2020, 8, 805. [CrossRef]

103. Vaishampayan, P.A.; Dhotre, D.P.; Gupta, R.P.; Lalwani, P.; Ghate, H.; Patole, M.S.; Shouche, Y.S. Molecular evidence and phylogenetic affiliations of Wolbachia in cockroaches. Molec. Phylogenet. Evol. 2007, 44, 1346-1351. [CrossRef] 
104. Lawrence, A.L.; Webb, C.E.; Clark, N.J.; Halajian, A.; Mihalca, A.D.; Miret, J.; D'Amico, G.; Brown, G.; Kumsa, B.; Modry, D.; et al. Out-of-Africa, human-mediated dispersal of the common cat flea, Ctenocephalides felis: The hitchhiker's guide to world domination. Int. J. Parasitol. 2019, 49, 321-336. [CrossRef] [PubMed]

105. Ashwini, M.S.; Puttalakshmamma, G.C.; Mamatha, G.S.; Chandranaik, B.M.; Thimmareddy, P.M.; Placid, E.; Jalali, S.K.; Venkatshan, T. Studies on morphology and molecular characterization of oriental cat flea infesting small ruminants by barcoding. J. Entomol. Zool. Stud. 2017, 5, 301-305.

(C) 2020 by the authors. Licensee MDPI, Basel, Switzerland. This article is an open access article distributed under the terms and conditions of the Creative Commons Attribution (CC BY) license (http://creativecommons.org/licenses/by/4.0/). 